\begin{abstract}
Introduction. This paper includes a description of an intervention model and research on the effectiveness of the model and associated practices that used child interest-based participation in everyday activities as sources of communication and language learning opportunities.

Methodology. The intervention included four components: (a) interest-based child learning opportunities, (b) everyday family and community activities as sources of child learning opportunities, (c) methods for increasing child participation in interest-based everyday activities, and (d) parents' use of responsive teaching for promoting child communication and language competence. The participants were 21 practitioners and 58 families of infants and toddlers with developmental delays. The intervention was implemented in the children's home by their parents an average of 12 months. Structural equation modeling was used to trace the effects of practitioner and parent fidelity of the intervention practices to rates of child language learning.

Results. The more children participated in interest-based everyday activities, the greater the growth in the children's language acquisition. The results also showed that practitioner and parent fidelity of use of the practices were indirectly related to changes in children's language development mediated by parents' judgments of the usefulness of the practices and the frequency of child participation in interest-based everyday activities.

Discussion and Conclusion. Results indicated that incorporating children's interests into everyday child language learning activities was an effective intervention strategy. The difference between practitioner- and parent-implemented everyday child language learning practices are described as are the implications for practice.
\end{abstract}

Keywords: Everyday activities, child interests, responsive teaching, practitioner coaching, language development.

\title{
Resumen
}

Introduccion. Este artículo presenta un modelo de intervención y una investigación centrado en la efectividad del modelo y en las prácticas asociadas que usan los intereses del niño para promover su participación en las actividades diarias para el aprendizaje de la comunicación y el lenguaje.

Metodología. La intervención constó de cuatro componentes: (a) oportunidades de aprendizaje basadas en el interés del niño, (b) actividades diarias de la familia y la comunidad entendidas como fuentes de oportunidades para el aprendizaje del niño, (c) métodos para aumentar la participación del niño en actividades diarias basadas en sus intereses, y (d) el uso por parte de los padres de una enseñanza responsiva para promover competencias de comunicación y lenguaje en el niño. Participaron 21 profesionales y 48 familias con niños con problemas en el desarrollo. La intervención se llevó a cabo en el hogar de los niños. Fueron los padres quienes la implementaron y duró una media de 12 meses. Se usó un modelo de ecuación estructural para trazar los efectos de la fidelización de los profesionales y los padres a las prácticas del programa en el índice de aprendizaje del lenguaje en el niño. 
Resultados. Cuanto más participaban los niños en actividades diarias basadas en sus intereses, mayor era el crecimiento en su adquisición del lenguaje. Los resultados también mostraron que la fidelidad de los padres y los profesionales al uso de las practicas estuvo indirectamente relacionada con los cambios en el desarrollo del lenguaje del niño, mediado a través de la valoración que los padres hacían sobre la utilidad de las prácticas y la frecuencia de la participación del niño en las actividades diarias basadas en su interés.

Discusión y Conclusiones. Los resultados indicaron que incorporar los intereses del niño en las actividades diarias de aprendizaje del lenguaje fue una estrategia de intervención efectiva. Se describen las diferencias entre la implementación por parte de los profesionales y el hecho que sean los padres quienes utilicen las prácticas en las actividades diarias para el aprendizaje del lenguaje en términos de implicaciones para la práctica.

Palabras claves: Actividades diarias, intereses del niño, enseñanza responsiva, profesional del coaching, desarrollo del lenguaje 


\section{Interest-Based Everyday Child Language Learning}

The purpose of this article is threefold. The first is to describe the key components of a communication and language intervention model that uses children's interests as the cornerstone of everyday child language learning opportunities. The second is to describe the procedures used to promote early childhood practitioner and parent use of the practices. The third is to describe the results from an evaluation of the effectiveness of the use of the model and associated practices. The language learning intervention model and associated practices are part of a line of research and practice on the person and environmental factors influencing child learning and development and parenting confidence and competence (e.g., Dunst et al., 2001; Dunst, Trivette, \& Raab, 2014; Raab, Dunst, \& Hamby, 2016).

The foundation of the model is the use of children's interests as a way of engaging and promoting child acquisition of functional and meaningful communication and language competence. Interests are either a person or situational (environmental) characteristic (Raab, 2005). Personal interests include a child's individual likes, preferences, favorites, strengths, and so forth that encourage and sustain child engagement and participation in desired and appealing activities. Situational interests include those aspects of the social and nonsocial environment that attract child attention, curiosity, and engagement in interactions with people and objects. The indicators of children's interests include, but are not limited to, sustained attention, arousal, curiosity, social-affective behavior (smiling and laughter), excitement, and prolonged engagement. Results from a meta-analysis of the relationships between children's interests and communication and language development indicate that incorporating either or both personal and 
situational interests into everyday activities is associated with optimal child benefits (Raab, Dunst, \& Hamby, 2013).

Figure 1 shows a framework for understanding the key characteristics of interest-based everyday learning opportunities that mirror what we know from available research evidence (see Dunst et al., 2001). Interest-based child learning engages children in interactions with people and objects that provide children opportunities to practice existing skills, explore their environments, and learn and master new abilities (Dunst, Jones, Johnson, Raab, \& Hamby, 2011; Dunst, Trivette, \& Hamby, 2012a; Raab \& Dunst, 2007). Nelson (1999), for example, noted that variations in the development of children's language competence were "related easily to the child's life activities and interests" (p. 2). It is now generally acknowledged that early communication and language skills are acquired most easily when learning opportunities are interest-based or have interest-based elements (e.g., Frijters, Barron, \& Brunello, 2000; O'Sullivan, 1997; Ortiz, Stowe, \& Arnold, 2001; Pruden, Hirsh-Pasek, Golinkoff, \& Hennon, 2006).

Insert Figure 1 About Here

\section{Everyday Child Language Intervention Model}

The language intervention model is shown in Figure 2. The model includes four components: interest-based child learning opportunities, everyday family and community activities as sources of language-rich child learning opportunities, methods and strategies for increasing child participation in interest-based everyday language learning activities, and the use of caregiver responsive teaching for supporting and strengthening children's communication and language 
competence. The reader is referred to Dunst et al. (2013a, 2013b, 2014) for detailed descriptions of the language intervention model and associated practices.

Insert Figure 2 About Here

\section{Language-Rich Everyday Activities}

Everyday activities include the many different kinds of experiences and opportunities afforded young children as part of daily living, child and family routines, family rituals, special events and outings, and family and community celebrations and traditions. The learning opportunities that happen as part of child participation in everyday activities have been found to be important contexts for child learning in general (e.g., Dunst, 2001; Kellegrew, 1998; Rogoff, Mistry, Göncü, \& Mosier, 1993) and child communication and language development more specifically (e.g., Duchan, 1995; Dunst, Valentine, Raab, \& Hamby, 2013; Kaiser \& Hester, 1996; Roper \& Gurley, 2006).

\section{Everyday Child Learning Opportunities}

Everyday activities can only have positive effects on learning and development if children have sufficient numbers of learning opportunities to participate in different kinds of activity settings having development-instigating and development-enhancing characteristics (Bronfenbrenner, 1992). Development-instigating refers to those child and environmental characteristics that invite, encourage, and sustain child interactions with people and objects. Developmentenhancing refers to the consequences of those interactions, including, but not limited to, child communication and language behavior and competence. 


\section{Interest-Based Child Learning}

Personal and situational interests are two of the many development-enhancing characteristics that influence child engagement and learning as part of participation in everyday activities (Dunst \& Raab, 2012; Raab \& Dunst, 2007). The focus of interest-based language learning is increasing both the frequency of child participation in different interest-based activities and the number of learning opportunities in each activity (Dunst, Raab, \& Trivette, 2013). Doing so provides parents and other caregivers opportunities to reinforce and support language learning while a child is engaged in the activities (Raab, Dunst, Johnson, \& Hamby, 2013).

\section{Caregiver-Mediated Child Learning}

Caregiver-mediated child learning involves parents' use of different methods and strategies for: (a) recognizing, identifying, and acknowledging child interests; (b) using this information for increasing child engagement in interest-based everyday learning activities; and (c) encouraging and supporting children's language learning and competence expression in the context of the everyday activities by using responsive teaching procedures. These abilities, taken together, are the key characteristics of a caregiver-mediated approach to interest-based everyday child communication and language learning (Dunst, Trivette, et al., 2013a, 2013b).

A particular approach to responsive teaching (Raab \& Dunst, 2009) is the primary instructional practice used to promote child communication and language development in the context of child participation in interest-based everyday family and community activities. A responsive interactional style is characterized by the timing, type, and appropriateness of a caregiver's sensitivity and responsiveness to child behavior and the extent to which a caregiver supports and encourages child communication and language behavior in everyday activities (Dunst, Raab, \& Trivette, 2011; Jennings \& Connors, 1989; Kim \& Mahoney, 2004). Findings 
from a number of research syntheses of studies of parental responsiveness to child behavior have identified the particular caregiver characteristics that matter most in terms of having optimal positive consequences (e.g., Dunst \& Kassow, 2008; Nievar \& Becker, 2008; Raab, Dunst, Johnson, et al., 2013).

\section{Promoting Practitioner and Parent Use of Interest-Based Child Language}

\section{Learning Practices}

The development, implementation, and evaluation of the language intervention model and practices was accomplished as part of a model-demonstration project where project staff facilitated early intervention practitioners' understanding and use of the model where practitioners in turn facilitated parents' use of the intervention model practices with their children. An implementation science framework (Kelly, 2012) was used to conceptualize and operationalize the relationships between project staff, practitioner, and parent practices, where practitioner and parent fidelity of use of the language intervention model and practices were expected to be related to differences in interest-based child learning opportunities and child language development (Carroll et al., 2007; Dunst, Trivette, \& Raab, 2013c). The project was implemented at four early intervention programs for infants and toddlers with identified disabilities and established developmental delays.

Project staff at each model demonstration site met with early intervention program practitioners $(\mathrm{N}=21)$ throughout the course of the project through face-to-face contacts, webinars, phone consultations, and emails to promote the practitioners understanding of and abilities to use the model and practices with the children and parents who were project participants. Half of the project staff-practitioner contacts were face-to-face (49.9\%) and one fourth of the contacts were phone consultations $(25.8 \%)$. There were 445 project staff-practitioner contacts during the course 
of the model demonstration portion of the project where each contact averaged just over one hour.

The early intervention practitioners met with the parents and children $(\mathrm{N}=58)$ during weekly or every other week home visits where they systematically introduced the different components of the language intervention model and used different tools (checklists, reminder lists, etc.) to facilitate parents' ongoing use of the practices with their children between home visits. The practitioners, on average, visited the parents and children twice per month over the course of 1012 months of intervention. The total number of home visits per family was, on average, 20-24 during the year of intervention.

An evidence-based approach to coaching (Dunst \& Trivette, 2009; Raab, Dunst, \& Trivette, 2013b) was used to promote practitioners' and parents' understanding and use of the language intervention practices. The particular approach to coaching used by the practitioners included the methods and procedures for (1) introducing and illustrating the practices to the parents, (2) engaging the parents in the use of the practices and their self-evaluation of their experiences, (3) the procedures used by the practitioners to facilitate parents' reflection on and understanding of the key characteristics of the practices, and (4) the procedures used to sustain parents' use of the interest-based language learning practices. This set of strategies was used by the practitioners as an evidence-based implementation practice to promote parents' adoption and use of the intervention practices with their children (Dunst, Bruder, \& Hamby, 2015; Dunst \& Hamby, 2015; Raab, Dunst, \& Trivette, 2013a) .

\section{Method}

The child language learning practices were evaluated extensively to determine whether the parent-mediated approach to intervention included practices that had the operationally-defined 
characteristics described earlier and had language-enhancing consequences. One focus of the evaluation was the relationship between early intervention practitioners' fidelity of coaching parents to use the practices and the fidelity of the parents' use of the intervention practices with their children. We also evaluated the extent to which parents' provision of interest-based child language learning opportunities was associated with differences in children's rates of language learning. We also evaluated the indirect effects of practitioners' fidelity of the coaching practices on parents' use of the intervention practices mediated by both parents' social validity judgments of the language learning practices and the frequency of their children's participation in interestbased everyday activities. These hypothesized relationships are based on an implementation science framework that has guided evaluation of other early childhood intervention practices (Dunst, Trivette, \& Raab, 2015).

The direct effects of practitioner coaching on parents' judgments of the importance and acceptability of the practices and parents' concerted effort to increase their children's participation in interest-based everyday activities is based on research about factors influencing parents' sustained use of evidence-based intervention practices (e.g., Dunst, Trivette, Gorman, \& Hamby, 2010). The direct effects of social validity and parents' engagement of their children in interest-based everyday activities with fidelity is based on findings from studies of factors associated with parents and practitioners' use of intervention practices with fidelity (Dunst, Pace, \& Hamby, 2007; Trivette, Dunst, Hamby, \& Pace, 2007).

\section{Participants}

The practitioners were 21 early intervention providers and 58 families in four U.S. Department of Education IDEA (Individuals with Disabilities Education Improvement Act of 2004, Pub. L. No. 108-446, 118 Stat. 2647, 2004) Part C Infant and Toddler Programs in three United States 
(North Carolina, Tennessee, and Delaware). They included early childhood-special educators, speech and language pathologists, special educators, and professionals from several other disciplines who worked with the parents and their children as part of involvement in the project and for whom we had the language outcome measure of interest.

The practitioners were, on average, 40.30 years of age $(\mathrm{SD}=12.39)$ and had, on average, 5.60 years $(\mathrm{SD}=8.36)$ of experience in early intervention programs. One third of the practitioners had bachelor's degrees and two-thirds had master's degrees. All of the practitioners were female.

The children all had identified disabilities or established developmental delays meeting each state's definition of eligibility for early intervention. The children were, on average, 22.33 months of age $(\mathrm{SD}=7.66)$ at the time of entry into the project. The majority of the children (91\%) were Caucasian whereas the other 9\% were African American, Latino or Hispanic, or another ethnicity.

The children's parents ranged between 19 and 57 years of age at the time of their children's initial involvement in the project $($ Mean $=34.09, \mathrm{SD}=8.78)$. Nine percent of the parents had completed less than a high school education, $28 \%$ were high school graduates, 35\% had completed some college, and $28 \%$ had at least a bachelor's degree. Eighty-four percent of the participants were the children's mothers, whereas $16 \%$ were the children's fathers or another family member.

\section{Procedure}

An investigator-developed checklist was used to assess practitioners' fidelity of use of the coaching practices with the parents. The checklist included 15 items measuring the extent to which practitioners engaged parents in identifying their children's interests, selecting interestbased everyday activities as sources of child language learning opportunities, increasing child 
participation in the activities, promoting parents' use of responsive teaching, and having parents evaluate the consequences of their use of the practices. The 15 items were each rated on a 5-point scale ranging from not-at-all the focus of parent engagement to a-great-deal the focus of parent engagement.

The parents completed an investigator-developed scale that included items for constructing several intervention variables as well as parents' fidelity of use of the intervention practices with their children. The parents' responses were used to determine (1) the frequency of child engagement in everyday language learning activities, (2) the use of the key characteristics of the intervention practices, and (3) parents' judgments of the social importance and acceptability of the practices. Parents indicated in how many different targeted language learning activities their children participated over the course of a designated week. The extent to which child engagement in the targeted everyday activities had interest-based characteristics (see Figure 1) was determined by five items each rated on a 5-point scale ranging from not-at-all-true to verymuch-true that child participation in the everyday activities were interest-based. Social validity of the practices was determined by four items, each rated on the same 5-point scale. Both the fidelity and social validity indicators have been used in other studies (e.g., Dunst, Pace, et al., 2007; Trivette et al., 2007).

The Preschool Language Scale (Zimmerman, Steiner, \& Pond, 2011) was used to measure child language development. The scale was administered to the children on 4 or 5 occasions over the course of approximately one year of intervention and during longitudinal follow-up. The scale was administered to the children by research assistants at regularly scheduled time intervals. The children's language age at each measurement occasion was the focus of analysis. Growth curve 
modeling (Raudenbush, Bryk, Cheong, Congdon, \& du Tolt, 2004) was used to compute for each child a rate-of-progress index which was used as the outcome measure in the project evaluation.

\section{Method of Analysis}

Structural equation modeling (SEM) was used to evaluate the direct and indirect effects of the predictor variables on the use of the key characteristics of the intervention practices with fidelity and child language learning. The SEM was performed using LISREL (Joreskog \& Sorborn, 2001) and the fit of the model to the hypothesized relationship among the variables was evaluated by both RMSEA (root mean square error of approximation) and CFI (comparative fit index). The closer RMSEA is to zero and the closer CFI is to one, the better the fit of the model to the data. The strength of the relationships among the variables was evaluated by the size of effects of the standardized structural coefficients. These coefficients can range from -1.0 to 1.0 and are indices of the direct effects of one variable in the model on another variable in the model. The indirect or mediated effects of a variable were estimated by the products of two direct effects (Kline, 2005).

\section{Results}

Figure 3 shows the SEM for evaluating the hypothesized relationships among the variables in the model. The RMSEA was 0.00 (90\% confidence interval $=0.00-0.19)$ and CFI was 1.00 , indicating a good fit of the model to the patterns of relationships in the data. Five of the eight standardized structural coefficients in the model were statistically significant. The pathways of influence between the variables in the model are highlighted to draw attention to how fidelity of the implementation and intervention practices can be traced to the frequency of interest-based child learning opportunity and children's rates of language acquisition. 
Practitioner fidelity of use of the coaching practices was related to parents' ratings of the social validity of the practices, $(\beta=.35, p=.003)$. The more socially valid parents judged the intervention practices, the more they engaged their children in everyday activities, $(\beta=.22, p=$ $.061)$ that were interest-based, $(\beta=.54, p=.000)$. The more frequently the parents engaged their children in interest-based everyday activities, $(\beta=.38, p=.002)$, the greater the growth in the children's language development, $(\beta=.32, p=.013)$.

In addition to the five direct effects, there were a number of indirect effects that further clarify the pathways of influence among the variables in the model. Practitioner fidelity of the coaching practices was indirectly related to the children's interest-based learning opportunities mediated by parents' social validity judgments, $(\beta=.35 \times .54=.19, p=.009)$. Parents' social validity judgments were indirectly related to the frequency of child participation in everyday activities mediated by interest-based child learning opportunities, $(\beta=.54 \times .38=.21, p=.008)$. And parents' engagement of their children in interest-based child learning opportunities was indirectly related to the rates of child language development mediated by the frequency of child participation in everyday activities, $(\beta=.38 \times .32=.12, p=.040)$.

\section{Conclusion}

The research and practice that are the foundations of the language intervention model described in this paper were examined with a specific focus on which child and environmental factors were associated with optimal positive child consequences. The consequences were defined as a child's rate of acquisition and use of communication and language interactive competencies. Findings from the evaluation of the language learning intervention practices showed that practitioners who 
successfully facilitated parents' understanding and use of the practices influenced parents' beliefs (social validity) about the value of the practices which in turn influenced their provision of interest-based child learning opportunities. The frequency of participation in everyday learning opportunities that were interest-based in turn was related to greater changes in the children's language acquisition.

A major lesson learned from our research and practice is that interest-based learning opportunities are, in almost every case, associated with more positive child consequences compared to non-interest-based learning opportunities (Bruder, Trivette, Dunst, \& Hamby, 2000; Dunst, 2011; Dunst et al., 2001; Dunst, Trivette, \& Cutspec, 2007; Swanson, Raab, \& Dunst, 2011). The findings from research syntheses of the relationships between child interests and positive child behavior consequences in general (Dunst, Trivette, \& Hamby, 2012b; Raab \& Dunst, 2007), and child communication and language development in particular (Dunst, Jones, et al., 2011; Raab, Dunst, \& Hamby, 2013), indicate that both personal and situational interests have development-instigating characteristics and development-enhancing consequences. Incorporating children's interests into early intervention practices therefore is warranted as a way to optimize child learning and development.

There has been a resurgence in attention to the role children's interests play in their learning and development (e.g., Kashdan \& Silvia, 2009; Liszkowski, Carpenter, Henning, Striano, \& Tomasello, 2004; Renninger \& Hidi, 2011; Silvia, 2005; Silvia, 2006). Studies of children with (e.g., Boyd, Alter, \& Conroy, 2005; Boyd, Conroy, Mancil, Nakao, \& Alter, 2007; Vismara \& Lyons, 2007) and without (e.g., DeLoache, Simcock, \& Macari, 2007; Johnson, Alexander, Spencer, Leibham, \& Neitzel, 2004; Leibham, Alexander, Johnson, Neitzel, \& Reis-Henrie, 2005) disabilities indicate that when learning opportunities use or build on children's interests, a 
host of positive effects are likely to be realized (see especially Renninger, Hidi, \& Krapp, 1992). The positive consequences include children's acquisition and use of both communication and language skills (Laakso, Poikkeus, Eklund, \& Lyytinen, 2004; Liszkowski et al., 2004; Pruden et al., 2006; Roper \& Gurley, 2006). These findings, as well as those from our own studies (e.g., Bruder et al., 2000; Dunst et al., 2001), are the foundations for using children's interests as a way of promoting communication and language learning using responsive teaching as an instructional practice for reinforcing child production of competence in interest-based activities.

\section{Implications for Types of Intervention Practices}

We conclude by noting a difference between traditional, practitioner-implemented intervention practices and those described in this paper, and why a parent-implemented, interest-based approach is warranted as an intervention model for young children with disabilities (Dunst, 2007; Dunst, Bruder, Trivette, \& Hamby, 2005). Traditional early intervention practices typically involve once or twice- a-week intervention or therapy sessions conducted by practitioners themselves. Some simple calculations indicate that twice-a-week hourly intervention or therapy in the absence of parent involvement accounts for only $2 \%$ of the total waking hours of a oneyear-old child (Roffwarg, Muzio, \& Dement, 1966), hardly enough time to make any real difference in a child's learning and development. Even when interventions are conducted in families' homes, parents are often not engaged in the use of the intervention practices with their children (Korfmacher et al., 2008; Korfmacher, Laszewski, Sparr, \& Hammel, 2012). In addition, findings from parent involvement studies indicates that many parents are not involved in their children's early intervention in ways that have capacity-building characteristics and consequences (Axford, Lehtonen, Kaoukji, Tobin, \& Berry, 2012; Dunst, Bruder, \& EspeSherwindt, 2014). 
In contrast to traditional intervention practices, nearly all everyday activities and routines (feeding, diaper changing, bathing, parent/child lap games, etc.) making up the fabric of a child's life is experienced at least 2000 times during the first year of a child's life (Ferrier, 1978) which are easily used as sources of interest-based child learning opportunities. Just 20 everyday activities would provide some 40,000 learning opportunities by age one. Research, however, indicates that infants, toddlers, and preschoolers with and without disabilities participate, on average, in about 50 different kinds of everyday activity (Dunst, Hamby, Trivette, Raab, \& Bruder, 2002). If each activity is experienced at least 2000 times a year, this translates into 100,000 learning opportunities each year of a child's life not counting the multiple number of learning opportunities afforded within any single activity. Assuming that any one activity provides only five learning opportunities (a very conservative estimate), the number of times a child has opportunities to practice existing and learn new skills would be about half a million learning opportunities (50 activities x 2000 times per year x 5 learning opportunities per activity equals 500,000). The fact is that any one activity can and often does include many more learning opportunities (e.g., bottle or spoon feeding). The same types of analyses performed by Mahoney and MacDonald (2007) and McWilliam (2000) resulted in the same conclusion that informal, everyday activities and interventions afforded young children provide them considerably more learning opportunities than do more traditional, practitioner-implemented intervention practices. The model and practices described in this paper for promoting child language learning is at least one approach to intervention that takes advantage of the everyday activities experienced by most children throughout the preschool years and beyond. 


\section{References}

Axford, N., Lehtonen, M., Kaoukji, D., Tobin, K., \& Berry, V. (2012). Engaging parents in parenting programs: Lessons from research and practice. Children and Youth Services Review, 34, 2061-2071. doi:10.1016/j.childyouth.2012.06.011

Boyd, B. A., Alter, P. J., \& Conroy, M. A. (2005, Spring). Using their restricted interests: A novel strategy for increasing the social behaviors of children with autism. Beyond Behavior, 3-9.

Boyd, B. A., Conroy, M. A., Mancil, G. R., Nakao, T., \& Alter, P. J. (2007). Effects of circumscribed interests on the social behaviors of children with autism spectrum disorders. Journal of Autism and Developmental Disorders, 37, 1550-1561. doi:10.1007/s10803-006-0286-8

Bronfenbrenner, U. (1992). Ecological systems theory. In R. Vasta (Ed.), Six theories of child development: Revised formulations and current issues (pp. 187-248). Philadelphia: Jessica Kingsley.

Bruder, M. B., Trivette, C. M., Dunst, C. J., \& Hamby, D. (2000, December). Comparative study of natural learning environment interventions to promote English language learning. Paper presented at the 16th Annual DEC International Early Childhood Conference on Children with Special Needs, Albuquerque, NM.

Carroll, C., Patterson, M., Wood, S., Booth, A., Rick, J., \& Balain, S. (2007). A conceptual framework for implementation fidelity. Implementation Science, 2, 40. doi:10.1186/17485908-2-40

DeLoache, J. S., Simcock, G., \& Macari, S. (2007). Planes, trains, automobiles--and tea sets: Extremely intense interests in very young children. Developmental Psychology, 43, 15791586. doi:10.1037/0012-1649.43.6.1579

Duchan, J. F. (1995). Supporting Language learning in everyday life. San Diego, CA: Singular

Dunst, C. J. (2001). Participation of young children with disabilities in community learning activities. In M. J. Guralnick (Ed.), Early childhood inclusion: Focus on change (pp. 307333). Baltimore, MD: Brookes.

Dunst, C. J. (2007). Early intervention with infants and toddlers with developmental disabilities. In S. L. Odom, R. H. Horner, M. Snell, \& J. Blacher (Eds.), Handbook of developmental disabilities (pp. 161-180). New York, NY: Guilford Press.

Dunst, C. J. (2011). Interest-based learning as an intervention practice for very young children with autism. In R. Holcraft (Ed.), Treatment strategies: Pediatrics (pp. 34-39). London, England: Cambridge Research Centre.

Dunst, C. J., Bruder, M. B., \& Espe-Sherwindt, M. (2014). Family capacity-building in early childhood intervention: Do context and setting matter? School Community Journal, 24(1), 37-48.

Dunst, C. J., Bruder, M. B., \& Hamby, D. W. (2015). Metasynthesis of in-service professional development research: Features associated with positive educator and student outcomes Educational Research and Reviews, 10(12), 1731-1744. doi:10.5897/ERR2015.2306

Dunst, C. J., Bruder, M. B., Trivette, C. M., Hamby, D., Raab, M., \& McLean, M. (2001). Characteristics and consequences of everyday natural learning opportunities. Topics in Early Childhood Special Education, 21, 68-92. doi:10.1177/027112140102100202

Dunst, C. J., Bruder, M. B., Trivette, C. M., \& Hamby, D. W. (2005). Young children's natural learning environments: Contrasting approaches to early childhood intervention indicate 
differential learning opportunities. Psychological Reports, 96, 231-234. doi:10.2466/pr0.96.1.231-234

Dunst, C. J., Hamby, D., Trivette, C. M., Raab, M., \& Bruder, M. B. (2002). Young children's participation in everyday family and community activity. Psychological Reports, 91, 875897. doi:10.2466/PR0.91.7.875-897

Dunst, C. J., \& Hamby, D. W. (2015). A case study approach to secondary reanalysis of a quantitative research synthesis of adult learning practices studies. International Journal of Learning, Teaching and Educational Research, 13(3), 181-191.

Dunst, C. J., Jones, T., Johnson, M., Raab, M., \& Hamby, D. W. (2011). Role of children's interests in early literacy and Language development. CELLreviews, 4(5), 1-18. Retrieved from http://www.earlyliteracylearning.org/cellreviews/cellreviews_v4_n5.pdf

Dunst, C. J., \& Kassow, D. Z. (2008). Caregiver sensitivity, contingent social responsiveness, and secure infant attachment. Journal of Early and Intensive Behavior Intervention, 5, 40-56. Retrieved from http://www.jeibi.com/.

Dunst, C. J., Pace, J., \& Hamby, D. W. (2007). Evaluation of the Games for Growing tool kit for promoting early contingency learning. Asheville, NC: Winterberry Press.

Dunst, C. J., \& Raab, M. (2012). Interest-based child participation in everyday learning activities. In N. M. Seel (Ed.), Encyclopedia of the sciences of learning (pp. 1621-1623). New York: Springer.

Dunst, C. J., Raab, M., \& Trivette, C. M. (2011). Characteristics of naturalistic language intervention strategies. Journal of Speech-Language Pathology and Applied Behavior Analysis, 5(3-4), 8-16. Retrieved from http://www.baojournal.com/SLPABA\%20WEBSITE/index.html

Dunst, C. J., Raab, M., \& Trivette, C. M. (2013). Methods for increasing child participation in interest-based language learning activities. Everyday Child Language Learning Tools, Number 4, 1-6.

Dunst, C. J., \& Trivette, C. M. (2009). Let's be PALS: An evidence-based approach to professional development. Infants and Young Children, 22(3), 164-175. doi:10.1097/IYC.0b013e3181abe169

Dunst, C. J., Trivette, C. M., \& Cutspec, P. A. (2007). Toward an operational definition of evidence-based practices. Asheville, NC: Winterberry Press.

Dunst, C. J., Trivette, C. M., Gorman, E., \& Hamby, D. W. (2010). Further evidence for the social validity of the Center for Early Literacy Learning practice guides. CELLpapers, 5(1), 1-3. $\quad$ Retrieved from http://www.earlyliteracylearning.org/cellpapers/cellpapers_v5n1.pdf

Dunst, C. J., Trivette, C. M., \& Hamby, D. W. (2012a). Effect of interest-based interventions on the social-communicative behavior of young children with autism spectrum disorders. CELLreviews, 5(6), 1-10. $\quad$ Retrieved from http://www.earlyliteracylearning.org/cellreviews/cellreviews_v15_n16.pdf.

Dunst, C. J., Trivette, C. M., \& Hamby, D. W. (2012b). Meta-analysis of studies incorporating the interests of young children with autism spectrum disorders into early intervention practices. Autism Research and Treatment, 2012, 1-10. doi:10.1155/2012/462531

Dunst, C. J., Trivette, C. M., \& Raab, M. (2013a). Caregiver-mediated everyday child language learning practices: I. Background and foundations. Everyday Child Language Learning Reports, Number 1, 1-8. $\quad$ Retrieved from http://www.cecll.org/download/ECLLReport_1_Backgrnd.pdf 
Dunst, C. J., Trivette, C. M., \& Raab, M. (2013b). Caregiver-mediated everyday child language learning practices: II. Intervention methods and procedures. Everyday Child Language Learning Reports, Number 2, 1-13. Retrieved from http://www.cecll.org/download/ECLLReport_2_Implementation.pdf

Dunst, C. J., Trivette, C. M., \& Raab, M. (2013c). An implementation science framework for conceptualizing and operationalizing fidelity in early childhood intervention studies. Journal of Early Intervention, 35(2), 85-101. doi:10.1177/1053815113502235

Dunst, C. J., Trivette, C. M., \& Raab, M. (2014). Everyday child language learning early intervention practices. Infants and Young Children, 27(3), 207-219. doi:10.1097/IYC.0000000000000015

Dunst, C. J., Trivette, C. M., \& Raab, M. (2015). Utility of implementation and intervention performance checklists for conducting research in early childhood education. In O. N. Saracho (Ed.), Handbook of research methods in early childhood education: Vol.1. Research methodologies (pp. 247-276). Charlotte, NC: Information Age Publishing.

Dunst, C. J., Valentine, A., Raab, M., \& Hamby, D. W. (2013). Everyday activities as sources of language learning opportunities for infants, toddlers, and preschoolers. Everyday Child Language Learning Reports, Number 6, 1-10. Retrieved from http://www.cecll.org/download/ECLLReport_16_Everyday.pdf.

Ferrier, L. (1978). Word, context and imitation. In A. Lock (Ed.), Action, gesture and symbol: The emergence of Language (pp. 471-483). London: Academic Press.

Frijters, J. C., Barron, R. W., \& Brunello, M. (2000). Direct and mediated influences of home literacy and literacy interests on prereaders' oral vocabulary and early written language skill. Journal of Educational Psychology, 92, 466-477.

Individuals with Disabilities Education Improvement Act of 2004, Pub. L. No. 108-446, 118 Stat. 2647. (2004).

Jennings, K. D., \& Connors, R. E. (1989). Mothers' interactional style and children's competence at 3 years. International Journal of Behavioral Development, 12, 155-175. doi:10.1177/016502548901200202

Johnson, K. E., Alexander, J. M., Spencer, S., Leibham, M. E., \& Neitzel, C. (2004). Factors associated with the early emergence of intense interests within conceptual domains. Cognitive Development, 19, 325-343. doi:10.1016/j.cogdev.2004.03.001

Joreskog, K. G., \& Sorborn, D. (2001). LISREL 8.5 for Windows. Skokie, IL: Scientific Software International.

Kaiser, A. P., \& Hester, P. P. (1996). How everyday environments support children's communication. In L. K. Koegel, R. L. Koegel, \& G. Dunlap (Eds.), Positive behavioral support: Including people with difficult behavior in the community (pp. 145-162). Baltimore, MD: Brookes.

Kashdan, T. B., \& Silvia, P. (2009). Curiosity and interest: The benefits of thriving on novelty and challenge. In S. J. Lopez \& C. R. Snyder (Eds.), Oxford handbook of positive psychology (2nd ed., pp. 367-374). New York, NY: Oxford University Press.

Kellegrew, D. H. (1998). Creating opportunities for occupation: An intervention to promote the self-care independence of young children with special needs. American Journal of Occupational Therapy, 52, 457-465. doi:10.5014/ajot.52.6.457

Kelly, B. (2012). Implementation science for psychology in education. In B. Kelly \& D. F. Perkins (Eds.), Handbook of implementation science for psychology in education (pp. 312). New York, NY: Cambridge University Press. 
Kim, J. M., \& Mahoney, G. (2004). The effects of mother's style of interaction on children's engagement: Implications for using responsive interventions with parents. Topics in Early Childhood Special Education, 24, 31-38. doi:10.1177/02711214040240010301

Kline, R. B. (2005). Principles and practice of structural equation modeling (2nd ed.). New York: Guilford Press.

Korfmacher, J., Green, B., Staerkel, F., Peterson, C., Cook, G., Roggman, L., . . . Schiffman, R. (2008). Parent involvement in early childhood home visiting. Child and Youth Care Forum, 37, 171-196. doi:10.1007/s10566-008-9057-3

Korfmacher, J., Laszewski, A., Sparr, M., \& Hammel, J. (2012). Assessing home visiting program quality: Final report to the Pew Center on the States. Philadelphia: The Pew Charitable Trusts.

Laakso, M.-L., Poikkeus, A.-M., Eklund, K., \& Lyytinen, P. (2004). Interest in early shared reading: Its relation to later language and letter knowledge in children with and without risk for reading difficulties. First Language, 24(3), 323-344. doi:10.1177/0142723704046041

Leibham, M. E., Alexander, J. M., Johnson, K. E., Neitzel, C. L., \& Reis-Henrie, F. P. (2005). Parenting behaviors associated with the maintenance of preschoolers' interests: A prospective longitudinal study. Journal of Applied Developmental Psychology, 26(4), 397-414. doi:10.1016/j.appdev.2005.05.001

Liszkowski, U., Carpenter, M. J., Henning, A., Striano, T., \& Tomasello, M. (2004). Twelvemonth-olds point to share attention and interest. Developmental Science, 7(3), 297-307. doi:10.1111/j.1467-7687.2004.00349.x

Mahoney, G., \& MacDonald, J. (2007). Autism and developmental delays in young children: The responsive teaching curriculum for parents and professionals. Austin, TX: PRO-ED.

McWilliam, R. A. (2000). It's only natural ... to have early intervention in the environments where it's needed. In S. Sandall \& M. Ostrosky (Eds.), Natural Environments and Inclusion (pp. 17-26). Longmont, CO: Sopris West.

Nelson, K. (1999, Winter). Making sense: Language and thought in development. Developmental Psychologist, 1-10. doi:10.1037/e517422010-517422002

Nievar, M. A., \& Becker, B. J. (2008). Sensitivity as a privileged predictor of attachment: A second perspective on De Wolff and van IJzendoorn's meta-analysis. Social Development, 17, 102-114. doi:10.1111/j.1467-9507.2007.00417.x

O'Sullivan, J. T. (1997). Effort, interest, and recall: Beliefs and behaviors of preschoolers. Journal of Experimental Child Psychology, 65(1), 43-67. doi:10.1006/jecp.1996.2355

Ortiz, C., Stowe, R. M., \& Arnold, D. H. (2001). Parental influence on child interest in shared picture book reading. Early Childhood Research Quarterly, 16(2), 263-281. doi:10.1016/s0885-2006(01)00101-6

Pruden, S. M., Hirsh-Pasek, K., Golinkoff, R. M., \& Hennon, E. A. (2006). The birth of words: Ten-month-olds learn words through perceptual salience. Child Development, 77(2), 266280. doi:10.1111/j.1467-8624.2006.00869.x

Raab, M. (2005). Interest-based child participation in everyday learning activities. CASEinPoint, 1(2), 1-5. Retrieved from http://www.fippcase.org/caseinpoint/caseinpoint_vol1_no2.pdf

Raab, M., \& Dunst, C. J. (2007). Influence of child interests on variations in child behavior and functioning. Asheville, NC: Winterberry Press.

Raab, M., \& Dunst, C. J. (2009). Magic seven steps to responsive teaching: Revised and updated. Asheville, NC: Winterberry Press. 
Raab, M., Dunst, C. J., \& Hamby, D. W. (2013). Relationships between young children's interests and early language learning. Everyday Child Language Learning Reports, No. 5. Retrieved from Available at http://www.cecll.org/products.php.

Raab, M., Dunst, C. J., \& Hamby, D. W. (2016). Effectiveness of contrasting approaches to response-contingent learning among children with significant developmental delays and disabilities. Research and Practice for Persons with Severe Disabilities, 41(1), 36-51. doi:10.1177/1540796915621189

Raab, M., Dunst, C. J., Johnson, M., \& Hamby, D. W. (2013). Influences of a responsive interactional style on young children's language acquisition. Everyday Child Language Learning Reports, Number 4, 1-23. Retrieved from http://www.cecll.org/download/ECLLReport_4_Responsive.pdf.

Raab, M., Dunst, C. J., \& Trivette, C. M. (2013a). Adult learning procedure for promoting caregiver use of everyday child language learning practices. Everyday Child Language Learning Reports, Number 3, 1-9. Retrieved from http://www.cecll.org/download/ECLLReport_3_AdultLearning.pdf.

Raab, M., Dunst, C. J., \& Trivette, C. M. (2013b). Adult learning procedure for promoting caregiver use of everyday child language learning practices. Everyday Child Language Learning Reports, Number 3, 1-9. Retrieved from Available at http://www.cecll.org/download/ECLLReport_3_AdultLearning.pdf.

Raudenbush, S. W., Bryk, A. S., Cheong, Y. F., Congdon, R. T., \& du Tolt, M. (2004). HLM 6: Hierarchical linear and nonlinear modeling. Lincolnwood, IL: Scientific Software International.

Renninger, K. A., \& Hidi, S. (2011). Revisiting conceptualization, measurement, and generation of interest. Educational Psychologist, 46, 168-184. doi:10.1080/00461520.2011.587723

Renninger, K. A., Hidi, S., \& Krapp, A. (Eds.). (1992). The role of interests in learning and development. Hillsdale, $\mathrm{NJ}$ : Erlbaum.

Roffwarg, H. P., Muzio, J. N., \& Dement, W. C. (1966). Ontogenetic development of the human sleep-dream cycle. Science, 152, 604-618.

Rogoff, B., Mistry, J., Göncü, A., \& Mosier, C. (1993). Guided participation in cultural activities by toddlers and caregivers. Monographs of the Society for Research in Child Development, 58(8, Serial No. 236).

Roper, N., \& Gurley, C. (2006). Activity setting influences on the early language production of a child with a cleft lip and palate. CASEinPoint, 2(1), 1-5. Retrieved from http://www.fippcase.org/caseinpoint/caseinpoint_vol2_no1.pdf

Silvia, P. J. (2005). What is interesting? Exploring the appraisal structure of interest. Emotion, 5(1), 89-102. doi:10.1037/1528-3542.5.1.89

Silvia, P. J. (2006). Exploring the psychology of interest. New York: Oxford University Press.

Swanson, J., Raab, M., \& Dunst, C. J. (2011). Strengthening family capacity to provide young children everyday natural learning opportunities. Journal of Early Childhood Research, 9, 66-80. doi:10.1177/1476718X10368588

Trivette, C. M., Dunst, C. J., Hamby, D. W., \& Pace, J. (2007). Evaluation of the Tune In and Respond tool kit for promoting child cognitive and social-emotional development. Asheville, NC: Winterberry Press.

Vismara, L. A., \& Lyons, G. L. (2007). Using perseverative interests to elicit joint attention behaviors in young children with autism: Theoretical and clinical implications for 
understanding motivation. Journal of Positive Behavior Interventions, 9, 214-228. doi:10.1177/10983007070090040401

Zimmerman, I. L., Steiner, V. G., \& Pond, R. E. (2011). Preschool Language Scales, Fifth Edition (PLS $S^{\text {TM}}$-5). San Antonio, TX: Psychological Corporation. 


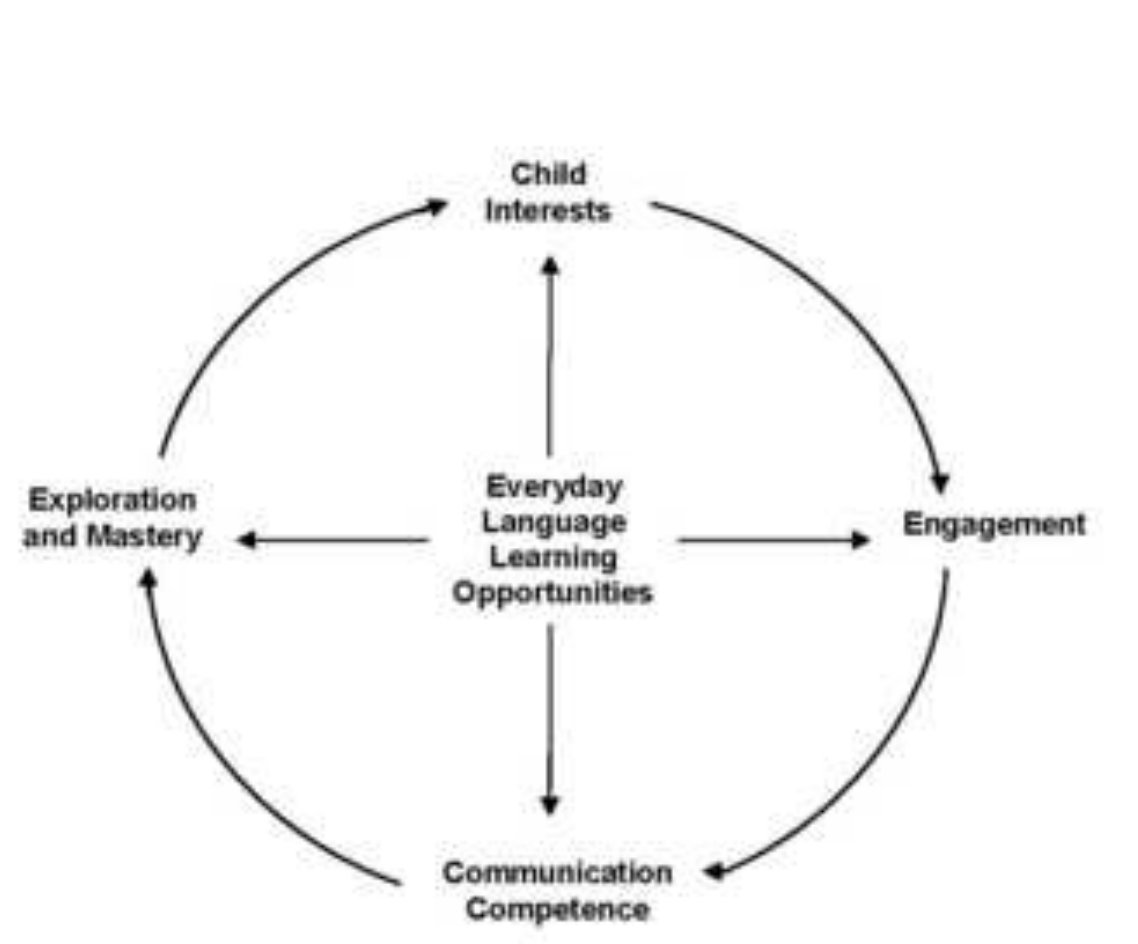

Figure 1. Model for depicting the flow of influences associated with interest-based

Figure 1. Model for depicting the flow of
everyday child language learning opportunities.

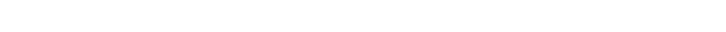

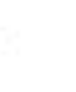

a




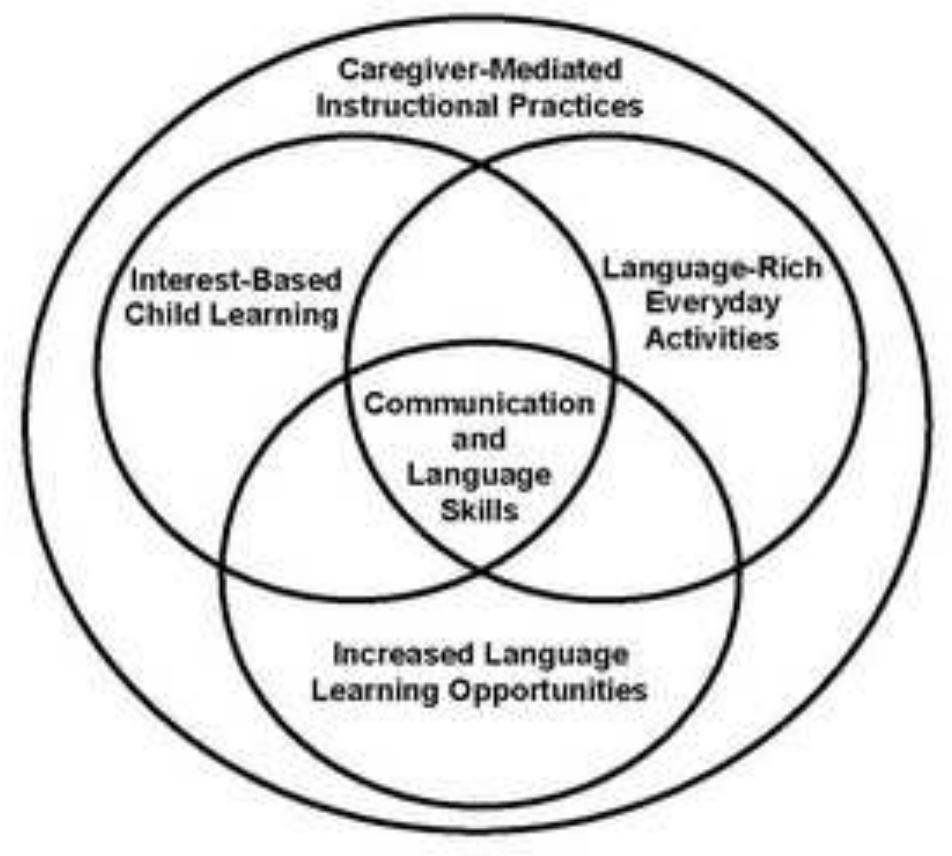

Figura model for facilitating young children's early communication and language skill acquisition.

. (1)

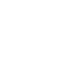




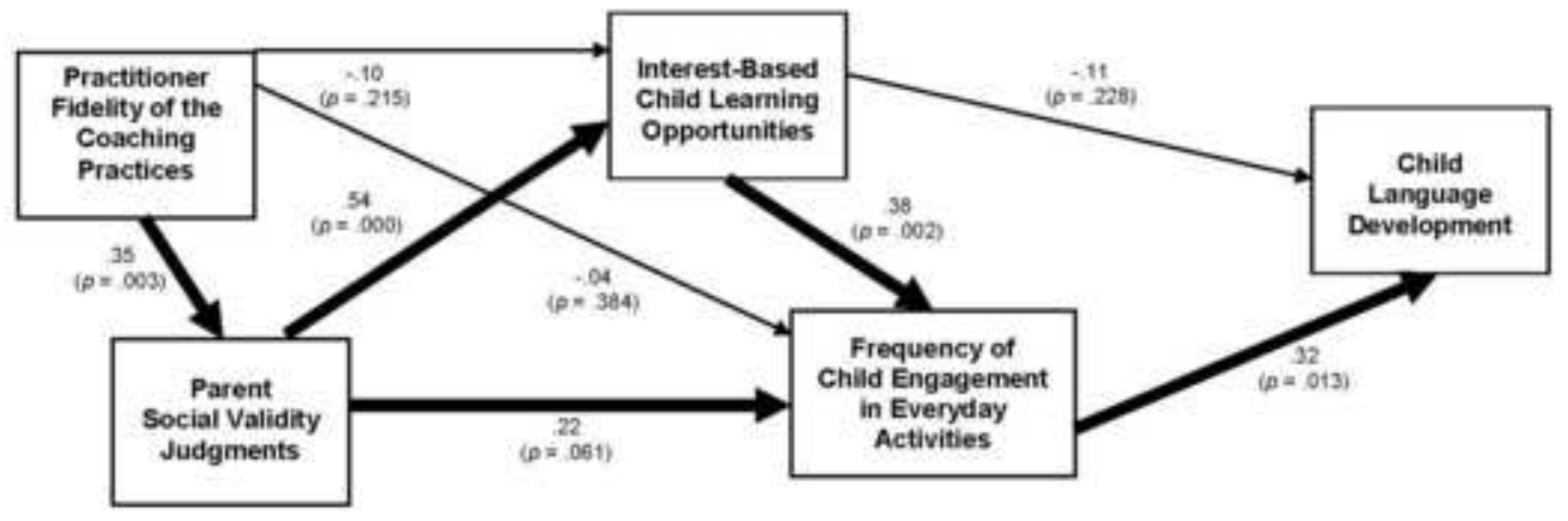

Figure 3. Pathways of influence of practitioner use of coaching and parents' use of interest-based child learning opportunities on children's rate of language acquisition. 